\title{
Glutamate-Dependent Phosphorylation of Elongation Factor-2 and Inhibition of Protein Synthesis in Neurons
}

\author{
Philippe Marin, ${ }^{1}$ Kent L. Nastiuk, ${ }^{2}$ Nadine Daniel, ${ }^{1}$ Jean-Antoine Girault, ${ }^{1}$ Andrew J. Czernik, ${ }^{2}$ \\ Jacques Glowinski, ${ }^{1}$ Angus C. Nairn, ${ }^{2}$ and Joël Prémont ${ }^{1}$ \\ ${ }^{1}$ Chaire de Neuropharmacologie, Institut National de la Santé et de la Recherche Médicale U114, Collège de France, \\ 75231 Paris Cedex 05, France, and 'Laboratory of Molecular and Cellular Neuroscience, The Rockefeller University, New \\ York, New York 10021
}

Postischemic delayed neuronal death is attributed to excitotoxic activation of glutamate receptors. It is preceded by a persistent inhibition of protein synthesis, the molecular basis of which is not known. Here we have examined in cortical neurons in culture the regulation by glutamate of phosphorylation of eukaryotic elongation factor-2 (eEF-2) by eEF-2 kinase, a $\mathrm{Ca}^{2+}$ / calmodulin-dependent enzyme. Using a phosphorylation statespecific antibody, we show that glutamate, which triggers a large influx of $\mathrm{Ca}^{2+}$, enhances dramatically the phosphorylation of eEF-2. On the basis of kinetic and pharmacological analysis, we demonstrate a close correlation among the increase in cytosolic $\mathrm{Ca}^{2+}$ concentration, the degree of eEF-2 phosphor- ylation, and the inhibition of protein synthesis. A 30 min treatment with NMDA induced a transient phosphorylation of eEF-2 and delayed neuronal death. However, pharmacological inhibition of protein translation was not neurotoxic by itself and protected neurons against the toxicity evoked by low concentrations of NMDA. Thus, phosphorylation of eEF-2 and the resulting depression of protein translation may have protective effects against excitotoxicity and open new perspectives for understanding long-term effects of glutamate.

Key words: elongation factor-2; phosphorylation; calcium; protein translation; glutamate; neuron
Glutamate is the major excitatory neurotransmitter in vertebrate brain, and stimulation of glutamate receptors plays a critical role in long-term synaptic plasticity (Bliss and Collingridge, 1993; Nicoll and Malenka, 1995). Overstimulation of glutamate receptors can induce delayed neuronal death, which has been implicated in the deleterious consequences of brain ischemia as well as in several neurodegenerative diseases (Coyle and Puttfarcken, 1993). Several lines of evidence suggest that glutamate inhibits protein synthesis in neurons. First, the massive release of glutamate occurring during cerebral ischemia (Benveniste et al., 1984) seems to be responsible for a persistent inhibition of neuronal protein synthesis, which precedes delayed neuronal death (Thilmann et al., 1986; Raley-Susman and Lipton, 1990). Second, the exposure of brain slices and cultured cerebellar granule cells to glutamate leads to a marked decrease in radioactive amino acid incorporation into proteins (Orrego and Lipmann, 1967; Vornov and Coyle, 1991; Dessi et al., 1994). However, the mechanism of this inhibition of protein synthesis is not known.

One important consequence of stimulation of glutamate receptors is a marked increase in cytosolic free $\mathrm{Ca}^{2+}$, a necessary step for the effects of glutamate on synaptic plasticity and for the

Received Dec. 23, 1996; revised Feb. 21, 1997; accepted Feb. 27, 1997.

This research was supported by grants from Institut National de la Santé et de la Recherche Médicale (INSERM), Direction des Recherches, Etudes et Techniques (DRET, contract 94/158), and Rhône Poulenc Rorer to J.P.; and United States Public Health Service Grant GM 50402 to A.C.N. We thank Gloria Bertuzzi for technical assistance and Dr. Kenichi Mitsui for preparation of eEF-2 and eEF-2 kinase.

Correspondence should be addressed to Dr. Joël Prémont, Chaire de Neuropharmacologie, Institut National de la Santé et de la Recherche Médicale U114, Collège de France, 11, Place Marcelin Berthelot, 75231 Paris Cedex 05, France, or Dr. Angus C. Nairn, Laboratory of Molecular and Cellular Neuroscience, The Rockefeller University, New York, New York 10021.

Copyright (C) 1997 Society for Neuroscience $0270-6474 / 97 / 173445-10 \$ 05.00 / 0$ induction of delayed neuronal death (Choi, 1992; Bliss and Collingridge, 1993; Nicoll and Malenka, 1995). Studies on protein translation in non-neuronal systems have indicated a role for $\mathrm{Ca}^{2+}$ in the inhibition of polypeptide elongation, which results from the phosphorylation of eukaryotic elongation factor-2 (eEF-2; for review, see Palfrey and Nairn, 1995). eEF-2 catalyzes the translocation of peptidyl-tRNA from the A site to the P site on the ribosome (Moldave, 1985). This protein is phosphorylated by eEF-2 kinase, a $\mathrm{Ca}^{2+} /$ calmodulin-dependent enzyme (Nairn and Palfrey, 1987; Ryazanov, 1987). eEF-2 is the sole substrate of this kinase and does not appear to be phosphorylated by any other kinase (Mitsui et al., 1993; Redpath and Proud, 1993). Three threonyl residues located at the $\mathrm{NH}_{2}$ terminus of eEF-2 can be phosphorylated by eEF-2 kinase in vitro (Ovchinnikov et al., 1990; Price et al., 1991; Redpath et al., 1993). Phosphorylation of Thr 56 alone seems to be responsible for the inhibition of mRNA translation in various cell-free systems (Nairn and Palfrey, 1987; Ryazanov et al., 1988; Redpath et al., 1993). Increases in eEF-2 phosphorylation on Thr 56 have been reported in living cells exposed to stimuli known to raise intracellular $\mathrm{Ca}^{2+}$ levels (Palfrey et al., 1987; Mackie et al., 1989; Hincke and Nairn, 1992). However, protein synthesis was not studied in these experimental systems.

The aim of the present study was to examine in neurons the possible role of phosphorylation of eEF-2 in the regulation of protein synthesis by glutamate. For that purpose we used cultured neurons from mouse cerebral cortex and took advantage of a novel approach, using an antibody that specifically recognizes eEF-2 phosphorylated at Thr 56.

\section{MATERIALS AND METHODS}

Primary culture of cortical neurons. Primary neuronal cultures were prepared as previously described (Weiss et al., 1986). Cultures, used 11-13 d 
after seeding, were shown to be highly enriched in neurons by immunocytochemistry for microtubule-associated protein 2 (MAP2; data not shown). Less than $7 \%$ of the cells were immunoreactive for glial fibrillary acid protein (data not shown).

Production and characterization of antibodies against total or phosphorylated $e E F-2$ and synapsin $I$. We previously have developed procedures to prepare antibodies that specifically recognize the unphosphorylated and phosphorylated forms of identified phosphorylation sites (Snyder et al., 1992; Czernik et al., 1995). The serum that specifically recognizes the phosphorylated form of eEF-2 (serum CC81) was obtained by immunization of rabbits with a peptide encompassing eEF-2 phosphorylation sites [GETRFT(P)DTRK]. This peptide was synthesized, and the threonine at the position corresponding to Thr 56 in the native protein was phosphorylated chemically, as described previously (Czernik et al., 1995). The serum recognizing total eEF-2 (serum G271) was obtained by immunization of rabbits with a peptide derived from the same region of the protein (ARAGETRFTDTRKD).

The phosphorylation of purified rabbit eEF-2 was achieved by incubating $350 \mathrm{ng}$ of eEF-2 for increasing times at $30^{\circ} \mathrm{C}$ in $100 \mu \mathrm{l}$ of medium containing $50 \mathrm{mM} \mathrm{HEPES/KOH}$ buffer, pH 7.6, $10 \mathrm{~mm}$ Mg-acetate, 150 $\mu \mathrm{M} \mathrm{CaCl}_{2}, 5 \mathrm{mM}$ dithiothreitol, $20 \mu \mathrm{g} / \mathrm{ml}$ calmodulin, $0.4 \mu \mathrm{g} / \mathrm{ml}$ purified eEF-2 kinase, $0.1 \mathrm{mg} / \mathrm{ml}$ bovine serum albumin, and $\left[\gamma-{ }^{32} \mathrm{P}\right] \mathrm{ATP}(50 \mu \mathrm{M}$, $3000 \mathrm{cpm} / \mathrm{pmol}$; Amersham, Les Ulis, France). Rabbit reticulocyte eEF-2 and eEF-2 kinase were purified as described previously (Mitsui et al., 1993). eEF-2 phosphorylation was determined by Cerenkov counting after SDS-PAGE. Proteins also were transferred electrophoretically to nitrocellulose sheets (Hybond-C, Amersham), which were incubated with the antibody directed against the phosphorylated form of eEF-2 (1:1000 dilution) or with the antibody raised against total eEF-2 (1:1000 dilution). Immunoreactivity was detected with an enhanced chemiluminescence method (Renaissance kit from New England Nuclear, France) using horseradish peroxidase-coupled donkey anti-rabbit secondary antibodies (Amersham). Immunoreactive bands were quantified by a computerassisted densitometer (Agfa-Gevaert SA, France).

The serum that specifically recognizes synapsin I phosphorylated at site 3 (CaM kinase II phosphorylation site, serum RU19) was produced in rabbit using a phosphopeptide corresponding to residues 597-607 [GPIRQAS(P)QAGP-amide] of rat synapsin I and was characterized as described previously (Czernik et al., 1995). The serum recognizing total synapsin I (serum G486) was produced against rat synapsin I and was purified over a synapsin I affinity column.

Analysis of eEF-2 and synapsin I phosphorylation in cortical neurons. Neurons grown for 11-13 d in six-well culture dishes were incubated for $2 \mathrm{~min}$, unless otherwise indicated, in $2 \mathrm{ml}$ of Krebs' bicarbonate buffer containing (in mM): $124 \mathrm{NaCl}, 3.5 \mathrm{KCl}, 1.25 \mathrm{~K}_{2} \mathrm{HPO}_{4}, 26.3 \mathrm{NaHCO}_{3}, 1.2$ $\mathrm{CaCl}_{2}$, and 10 glucose, previously equilibrated with $95 \% \mathrm{O}_{2} / 5 \% \mathrm{CO}_{2}$ and prewarmed at $37^{\circ} \mathrm{C}$ in the presence of drugs. Incubations were stopped by replacing the medium with $0.2 \mathrm{ml}$ of boiling $\operatorname{SDS}(1 \%, \mathrm{w} / \mathrm{v})$ to prevent protein dephosphorylation by phosphatases. Protein concentration was determined with a bicinchoninic acid method (Smith et al., 1985), using bovine serum albumin as standard. Samples containing $50 \mu \mathrm{g}$ of protein were resolved on $8 \%$ polyacrylamide gels and transferred to nitrocellulose. eEF-2 phosphorylation was analyzed by sequential immunoblotting with the antibody specifically recognizing the phosphorylated form of eEF-2 (1:1000 dilution) and that recognizing total eEF-2 (1:1000 dilution). The chemiluminescence signals corresponding to different amounts of purified eEF-2 were used as a calibration curve to estimate the amount of eEF-2 in neuronal homogenates. Similarly, the chemiluminescence signals corresponding to different amounts of purified ${ }^{32} \mathrm{P}$-phosphoeEF-2 were used as a calibration curve to determine the stoichiometry of neuronal eEF-2 phosphorylation. Because the amino acid sequence of eEF-2 is very highly conserved between species, with the sequence surrounding the phosphorylation sites being completely conserved in human, rat, and hamster, we assumed that the antibodies reacted equally well with rabbit and mouse eEF-2. Synapsin I phosphorylation was analyzed by sequential immunoblotting with the antibody specifically recognizing synapsin I phosphorylated on Ser 603 (1:1000 dilution) and that recognizing synapsin I independently of its state of phosphorylation (1:5000 dilution).

Immunocytochemistry experiments. Immunostaining experiments were performed on cortical neurons cultured on glass slides for 9-10 d by indirect immunofluorescence, as described by Chamak et al. (1987). Phospho-eEF-2 and total eEF-2 were detected in neurons treated or not for $5 \mathrm{~min}$ with glutamate $(100 \mu \mathrm{M})$, using the antibody recognizing either the phosphorylated form of eEF-2 (1:1000 dilution) or eEF-2 regardless of its phosphorylation state (1:1000 dilution). These antibodies were visualized by a fluorescein-conjugated goat antibody to rabbit IgG (1:100 dilution; Southern Biotechnology Associates, Birmingham, AL).

Measurement of eEF-2 kinase activity in cytosolic extracts. Neurons were homogenized in $20 \mathrm{~mm}$ Tris $\mathrm{HCl}, \mathrm{pH} 7.6,1 \mathrm{~mm}$ EDTA, and $1 \mathrm{~mm}$ EGTA. Samples were centrifuged at $450,000 \times g$ for $6 \mathrm{~min}$. eEF-2 kinase activity was determined in supernatants (cytosolic extracts) as described above, using $5 \mu \mathrm{g}$ of protein, by measuring the incorporation of ${ }^{32} \mathrm{P}$ in $100 \mathrm{ng}$ of purified rabbit eEF-2 in the presence of $1 \mathrm{mM}$ EGTA and, when indicated, $1.5 \mathrm{mM} \mathrm{Ca}^{2+}$ and $20 \mu \mathrm{g} / \mathrm{ml}$ calmodulin.

Measurement of $\left[{ }^{35}\right.$ S]methionine and $\left[{ }^{3} H\right]$ leucine incorporation. Neurons grown in 12-well culture dishes were washed twice in $1 \mathrm{ml}$ of Krebs' bicarbonate buffer and then incubated for $5 \mathrm{~min}$ in this medium in the presence of drugs and $4 \mu \mathrm{Ci} / \mathrm{ml}$ of either $\left[{ }^{35} \mathrm{~S}\right]$ methionine $(1000 \mathrm{Ci} / \mathrm{mmol}$, Amersham) or $\left[{ }^{3} \mathrm{H}\right]$ leucine $(159 \mathrm{Ci} / \mathrm{mmol}$, Amersham). The labeling was stopped by two washes in $1 \mathrm{ml}$ of ice-cold PBS and the addition of $1 \mathrm{ml}$ of ice-cold trichloroacetic acid (TCA; 10\%, w/v). Cells were scraped, and suspensions were centrifuged for $10 \mathrm{~min}$ at $10,000 \times \mathrm{g}$. Amino acid uptake into neurons and incorporation into proteins were estimated by counting the radioactivity in the supernatant and the pellet, respectively.

Cytosolic $\mathrm{Ca}^{2+}$ measurement. Cytosolic free $\mathrm{Ca}^{2+}$ was monitored in neurons cultured on glass slides by quantitative ratio imaging of the fluorescent $\mathrm{Ca}^{2+}$ probe INDO-1 (Molecular Probes, Eugene, OR), as described previously (Murphy et al., 1994). Cytosolic $\mathrm{Ca}^{2+}$ concentration was calculated according to the equation described by Grynkiewicz (Grynkiewicz et al., 1985), with a dissociation constant for INDO-1 (kDa) of $250 \mathrm{nM}:\left[\mathrm{Ca}^{2+}\right]=\mathrm{kDa} \times\left(F_{480 \mathrm{f}} / F_{480 \mathrm{~b}}\right) \times\left(R-R_{\min }\right) /\left(R_{\max }-R\right)$, in which $F_{480 \mathrm{f}}$ is the fluorescence of free INDO- 1 and $F_{480 \mathrm{~b}}$ is the fluorescence of INDO- 1 bound to $\mathrm{Ca}^{2+}, R$ is the ratio between fluorescences measured at 405 and $480 \mathrm{~nm}$, and $R_{\min }$ and $R_{\max }$ were determined in the presence of ionomycin $(10 \mu \mathrm{M})$ and either EGTA $(2 \mathrm{~mm})$ or $\mathrm{CaCl}_{2}(2$ $\mathrm{mM})$, respectively.

Measurement of neuronal survival. After exposures to glutamate, neurons were incubated with 3-(4,5-dimethylthiazol-2-yl)-2,5, diphenyl tetrazolium bromide (MTT; $0.5 \mathrm{mg} / \mathrm{ml}$ ) in PBS supplemented with glucose (33 $\mathrm{mM}$ ) for $30 \mathrm{~min}$. The blue formazan produced was solubilized in $1 \mathrm{ml}$ of dimethyl sulfoxide, and optical density was read at $560 \mathrm{~nm}$.

\section{RESULTS}

\section{Phosphorylation of eEF-2 in cortical neurons exposed to glutamate}

The phosphorylation of eEF-2 expressed in cultured cortical neurons was assessed by immunoblot experiments, using an antibody raised against a peptide encompassing the eEF-2 phosphorylation sites and phosphorylated on a threonyl residue corresponding to Thr 56 in the native protein. This antibody specifically recognized the phosphorylated form of eEF-2 (phospho-eEF-2). Indeed, when purified rabbit eEF-2 was incubated with purified eEF-2 kinase and $\left[\gamma_{-}{ }^{32} \mathrm{P}\right] \mathrm{ATP}$, a time-dependent increase in immunoreactivity measured by using this antibody occurred concurrently with the increase in phosphorylation level measured by ${ }^{32} \mathrm{P}$ incorporation (Fig. 1). Treatment of cortical neurons with glutamate $(100 \mu \mathrm{M})$ resulted in a marked increase in eEF-2 phosphorylation, as measured by using the phospho-eEF-2-specific antibody (Fig. 2). The maximal level of eEF-2 phosphorylation induced by glutamate was achieved in $<30 \mathrm{sec}$ and was maintained for at least 5 min (Fig. 2). Immunoblotting experiments performed with an antibody that recognized total eEF- 2 indicated that its amount remained unchanged in neurons during treatment with glutamate (Fig. 2).

The stable level of eEF-2 phosphorylation observed from 0.5 to 5 min after glutamate application suggests an equilibrium between the activities of eEF-2 kinase and phosphatase, which is likely to be phosphatase 2A (Nairn and Palfrey, 1987; Redpath and Proud, 1990). However, during the first minutes of glutamate treatment, phosphatase activity did not appear to be a limiting factor for eEF-2 phosphorylation because okadaic acid, a nonselective inhibitor of phosphatase $2 \mathrm{~A}$ at the concentration used in our ex- 


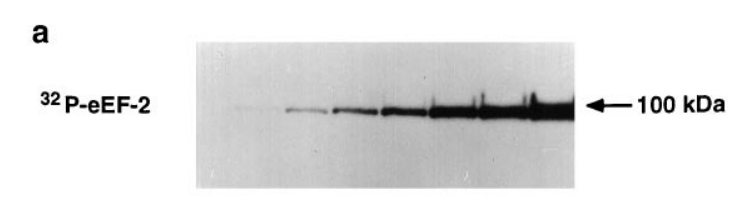

b

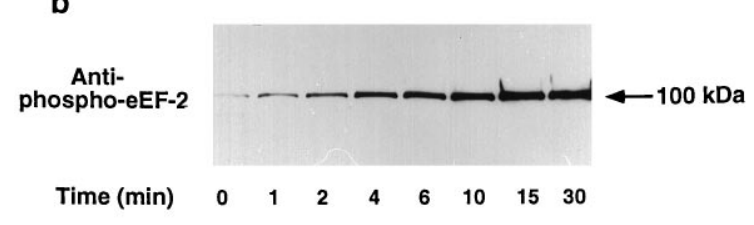

c

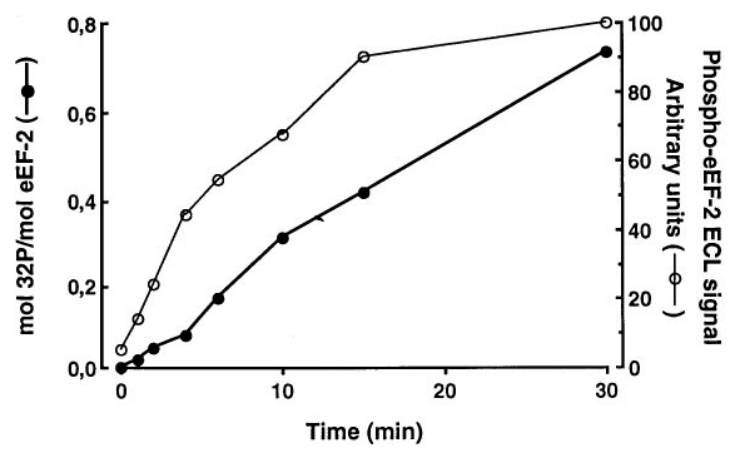

Figure 1. Analysis of eEF-2 phosphorylation with a phospho-eEF-2 specific antibody. Purified rabbit eEF-2 was incubated with purified eEF-2 kinase and $\left[\gamma^{32} \mathrm{P}\right]$ ATP for increasing times. $a$, Incorporation of ${ }^{32} \mathrm{P}$ in eEF-2 (35 ng/lane) was detected by autoradiography. $b$, Aliquots from the same samples were examined by immunoblotting with an antibody raised against a peptide encompassing eEF-2 phosphorylation sites and synthesized with a chemically phosphorylated threonine corresponding to Thr 56 in the native protein. Immunoreactivity was detected with a horseradish peroxidase-coupled secondary antibody using an enhanced chemiluminescence method and autoradiography. $c$, Incorporation of ${ }^{32} \mathrm{P}$ in eEF-2 and in phospho-eEF-2 immunoreactivity was quantified by Cerenkov counting and computer-assisted densitometric analysis, respectively.

periments $(1 \mu \mathrm{M})$, did not significantly enhance the phosphorylation of eEF-2 induced by a 2 min exposure to glutamate (112 \pm $9 \%$ of the glutamate effect, mean \pm SEM of densitometric analyses of immunoreactive bands obtained with the anti-phosphoeEF-2 antibody in three independent experiments; see also Fig. 2). On the other hand, when it was added alone, okadaic acid was unable to increase the phosphorylation of eEF-2 (Fig. 2), suggesting that the activity of eEF-2 kinase is very low in the absence of glutamate.

Immunocytochemical staining performed with the phosphoeEF-2-specific antibody indicated that a 5 min exposure to $100 \mu \mathrm{M}$ glutamate strongly increased the phosphorylation of eEF-2 in $\sim 50 \%$ of cultured cortical neurons, whereas no detectable response or a slight increase in immunoreactivity was observed in other neurons (Fig. 3b, d; 200 neurons originating from two independent cultures were counted). The phosphorylated form of eEF-2 was not detected in cells with glial morphology after glutamate treatment (data not shown). As expected, all cells, including glial cells, were stained with the antibody recognizing eEF-2 regardless of its phosphorylation state (Fig. $3 e, f$ ). In cells with neuronal morphology, eEF-2 was localized in cell bodies as well as in neuronal processes (Fig. 3e,f). In contrast, the increase in eEF-2 phosphorylation within stimulated neurons was detected

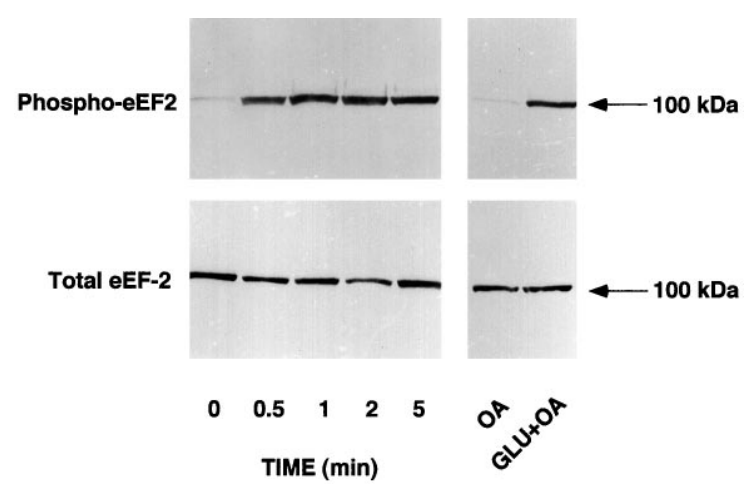

Figure 2. Increase in eEF-2 phosphorylation in cortical neurons exposed to glutamate. Cortical neurons grown in culture for 11-13 d were incubated with $100 \mu \mathrm{M}$ glutamate for the indicated times. Cells were harvested in boiling SDS, and proteins $(50 \mu \mathrm{g} /$ lane $)$ were resolved on $8 \%$ SDSpolyacrylamide gels and transferred to nitrocellulose sheets. Immunoblotting was performed with the anti-phospho-eEF-2 antibody or the antibody reacting with total eEF-2. Immunoreactive bands were detected with a horseradish peroxidase-coupled secondary antibody, chemiluminescence, and autoradiography. Neurons also were preincubated with okadaic acid $(O A, 1 \mu \mathrm{M})$ for $30 \mathrm{~min}$, and glutamate $(G L U, 100 \mu \mathrm{M})$ was added to cells for an additional $2 \mathrm{~min}$ incubation period. The data illustrated are representative of three experiments, each performed on different sets of cultured neurons.

only in cell bodies and proximal neurites, but not in distal processes (Fig. 3d).

\section{Involvement of NMDA and AMPA receptors in the glutamate-induced phosphorylation of eEF-2}

We investigated the pharmacological profile of the glutamate response to identify the receptors involved in the regulation of eEF-2 phosphorylation. A 2 min application of maximally effective concentrations of either NMDA $(200 \mu \mathrm{M})$ or AMPA $(30 \mu \mathrm{M})$ increased the phosphorylation of eEF-2, although AMPA was less efficient than NMDA (Fig. 4, Table 1). It should be noted that all treatments were performed in the absence of extracellular $\mathrm{Mg}^{2+}$ to avoid the $\mathrm{Mg}^{2+}$ - and voltage-dependent block of NMDA-gated channels (Nowak et al., 1984). The study of the effects of antagonists confirmed the role of both AMPA and NMDA receptors in the regulation of eEF-2 phosphorylation. Indeed, complete inhibition of the glutamate response required the joint application of NMDA and AMPA antagonists, (+)-5-methyl-10,11-dihydro-5Hdibenzo[a,d]-cyclohepten-5,10-imine hydrogen maleate (MK-801, $2 \mu \mathrm{M})$ and 6-cyano-2,3-dihydroxy-7-nitroquinoxaline-2,3-dione (CNQX, $100 \mu \mathrm{M})$, respectively, whereas either antagonist alone had only a small effect (Fig. 4). Finally, the selective metabotropic receptor agonist 1S,3R-trans- $( \pm)$-1-amino-1,3-cyclopentanedicarboxylic acid (trans-ACPD, $300 \mu \mathrm{M}$ ) did not increase significantly eEF-2 phosphorylation (Fig. 4, Table 1), indicating that this class of receptor does not contribute to the glutamate-induced phosphorylation of eEF-2 in cortical neurons in culture.

\section{Role of $\mathrm{Ca}^{2+}$ in the glutamate-induced phosphorylation of eEF-2}

It has been demonstrated that $\mathrm{Ca}^{2+}$ is the main factor responsible for the activation of eEF-2 kinase (Mitsui et al., 1993; Redpath and Proud, 1993). Accordingly, a strong correlation was observed between the increase in cytosolic free $\mathrm{Ca}^{2+}$ concentration and the phosphorylation of eEF-2 induced by various treatments in cortical neurons (Table 1). Glutamate and NMDA, which induced the highest increase in cytosolic $\mathrm{Ca}^{2+}$ concentration, were also the most 

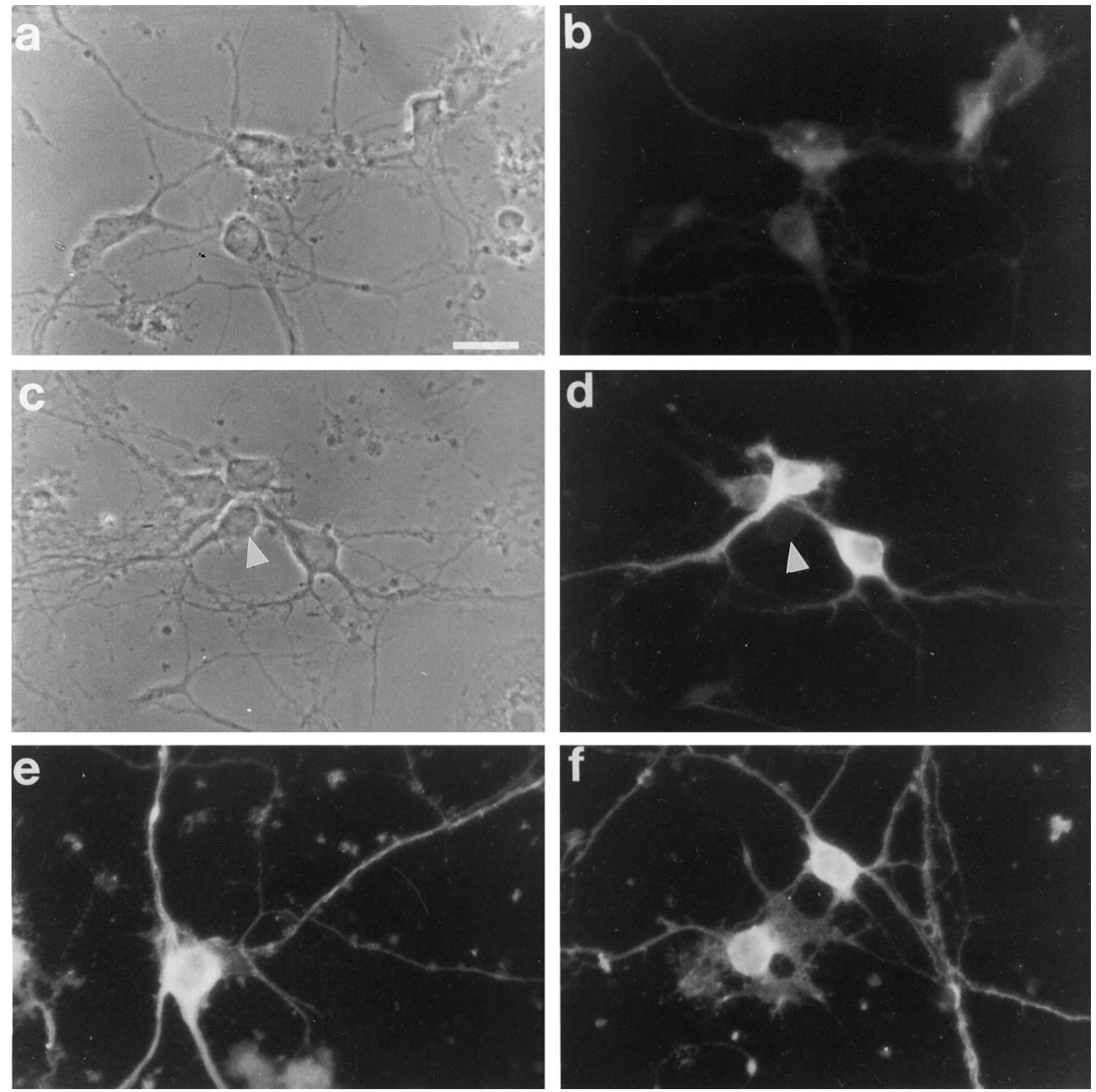

Figure 3. Immunofluorescent localization of total and phospho-eEF-2 in cortical neurons. $a, c$, Phase-contrast photomicrographs of untreated cortical neurons $(a)$ and neurons exposed for $5 \mathrm{~min}$ to $100 \mu \mathrm{M}$ glutamate $(c) . b, d$, Corresponding immunofluorescence photomicrographs using the anti-phospho-eEF-2 antibody. $e, f$, Representative immunofluorescence photomicrographs of cells exposed to sham treatment $(e)$ or glutamate $(f)$ and immunostained with the antibody recognizing eEF-2 regardless of its phosphorylation state. No detectable staining was observed in cells incubated only with the secondary antibody to rabbit IgG (not shown). Arrowhead, Neuron insensitive to glutamate treatment. Scale bar, $20 \mathrm{~mm}$.

effective agonists in stimulating eEF-2 phosphorylation (Table 1). A 2 min application of the maximally effective concentration of AMPA $(30 \mu \mathrm{M})$ or potassium-induced depolarization $(\mathrm{KCl}, 50 \mathrm{~mm})$ led to both intermediate elevations of cytosolic $\mathrm{Ca}^{2+}$ concentration and phosphorylation level of eEF-2 (Table 1). Despite its ability to stimulate phospholipase C in cortical neurons (Trovéro et al., 1994), trans-ACPD was unable to increase cytosolic $\mathrm{Ca}^{2+}$ in this neuronal population. This is in agreement with its lack of effect on eEF-2 phosphorylation (Table 1). Further supporting the role of $\mathrm{Ca}^{2+}$ in the regulation of eEF-2 phosphorylation, both the elevation of cytosolic $\mathrm{Ca}^{2+}$ (data not shown) and the phosphorylation of eEF-2 induced by the aforementioned treatments were suppressed in the absence of extracellular $\mathrm{Ca}^{2+}$ and the presence of $1 \mathrm{mM}$ EGTA (Fig. 4). However, it should be noted that removal of extracellular $\mathrm{Ca}^{2+}$ by itself caused a slight increase in the level of eEF-2 phosphorylation (Fig. 4).

\section{Reversibility of the glutamate-induced phosphorylation of eEF-2}

To investigate the reversibility of the glutamate-induced phosphorylation of eEF-2, we added glutamate $(100 \mu \mathrm{M})$ to cells for 30 sec. In this experimental condition, cytosolic $\mathrm{Ca}^{2+}$ concentration increased transiently and returned to the basal level in $<2 \mathrm{~min}$ (Fig. 5). The level of eEF-2 phosphorylation decreased with a slower time course, the complete dephosphorylation of eEF-2 occurring within 5 min (Fig. 5).

\section{Correlation between eEF-2 phosphorylation and protein synthesis inhibition}

Using purified unphosphorylated and phosphorylated rabbit eEF-2 as standards, we estimated that cortical neurons contained $7.5 \pm 0.5 \mu \mathrm{g}$ of eEF- $2 / \mathrm{mg}$ protein (mean \pm SEM of three determinations performed on different cultures, $n=3$ ) and that $44 \pm$ 


\section{Molecular weight (x10-3)}

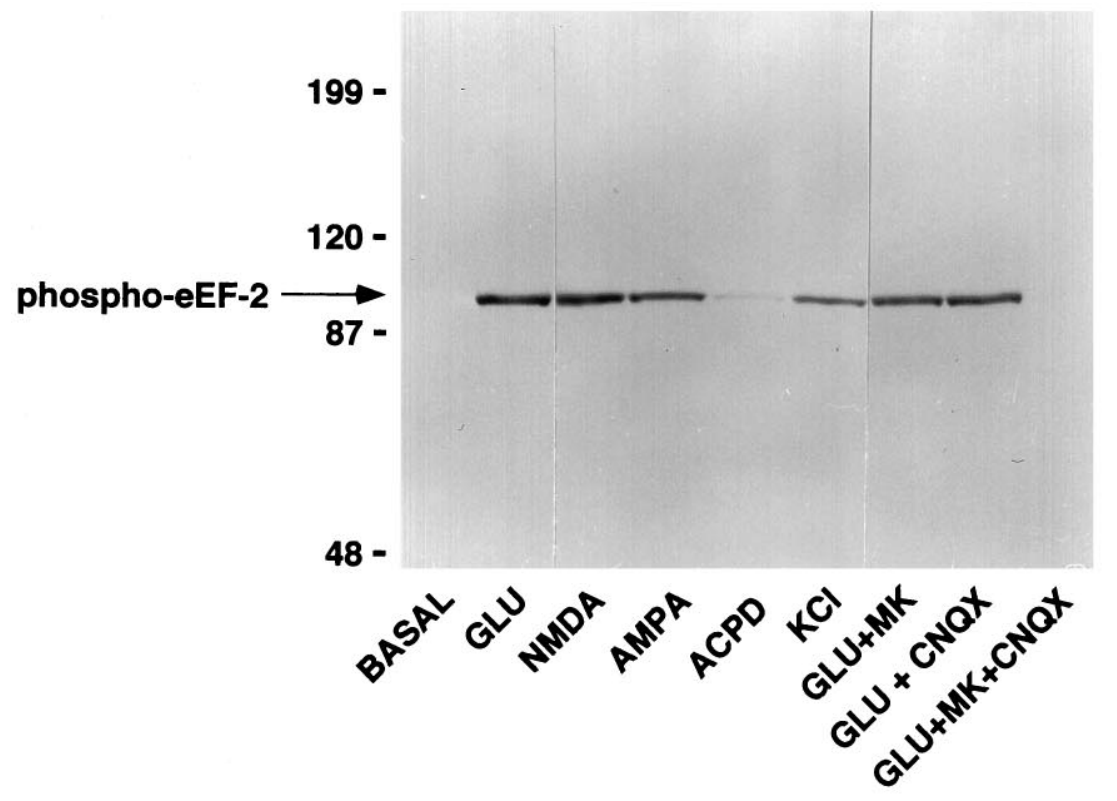

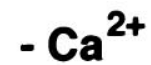

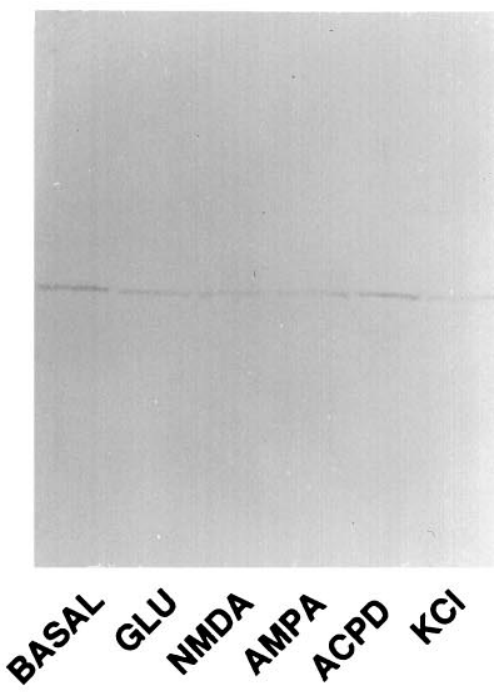

Figure 4. Role of $\mathrm{Ca}^{2+}$ in the phosphorylation of eEF-2 induced by glutamatergic receptor agonists or cell depolarization. Left panel $\left(+\mathrm{Ca}^{2+}\right)$, Cortical

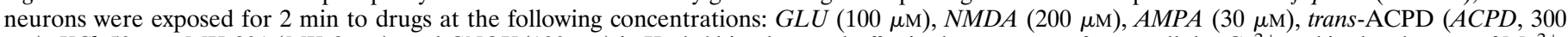
$\mu \mathrm{M}), K C l, 50 \mathrm{mM}, \mathrm{MK}-801(\mathrm{MK}, 2 \mu \mathrm{M})$, and $C N Q X(100 \mu \mathrm{M})$ in Krebs' bicarbonate buffer in the presence of extracellular $\mathrm{Ca}^{2+}$ and in the absence of $\mathrm{Mg}^{2+}$. MK-801 and CNQX were added to cells 1 min before glutamate application. Phosphorylation of eEF-2 was measured by immunoblotting with the anti-phospho-eEF-2 antibody, as described in the legend to Figure 2. MK-801 and CNQX, added alone or simultaneously, did not significantly alter the basal level of eEF-2 phosphorylation in neurons. Right panel $\left(-\mathrm{Ca}^{2+}\right)$, Neurons were incubated in the absence of extracellular $\mathrm{Ca}^{2+}$ and in the presence of EGTA (1 mM) for $5 \mathrm{~min}$ before drug application. The data illustrated are representative of three experiments, each performed on different sets of cultured neurons.

$5 \%(n=3)$ of eEF-2 was phosphorylated after a 2 min glutamate treatment. This relatively high stoichiometry of phospho-Thr 56 raised the possibility that eEF-2 phosphorylation was involved in glutamate-dependent inhibition of protein translation in cortical neurons. We observed a strong inhibition of $\left[{ }^{35} \mathrm{~S}\right]$ methionine incorporation into proteins in cortical neurons exposed to agonists of ionotropic glutamate receptors or a depolarizing concentration (50 mM) of $\mathrm{KCl}$ (Fig. 6). Similar results were obtained with

\section{Table 1. Correlation between eEF-2 phosphorylation level and cytosolic} $\mathrm{Ca}^{2+}$ concentration

\begin{tabular}{llr} 
Treatment & $\begin{array}{l}\text { Phospho-eEF-2 } \\
(\% \text { of glutamate effect })\end{array}$ & \multicolumn{1}{c}{$\left[\mathrm{Ca}^{2+}\right](\mathrm{nM})$} \\
\hline None & $15 \pm 5$ & $90 \pm 10$ \\
trans-ACPD $(300 \mu \mathrm{M})$ & $17 \pm 4$ & $94 \pm 17$ \\
KCl $(50 \mathrm{mM})$ & $62 \pm 7$ & $489 \pm 11$ \\
AMPA $(30 \mu \mathrm{M})$ & $78 \pm 10$ & $596 \pm 44$ \\
NMDA $(200 \mu \mathrm{M})$ & $95 \pm 1$ & $1080 \pm 50$ \\
Glutamate $(100 \mu \mathrm{M})$ & 100 & $1154 \pm 65$
\end{tabular}

The phosphorylation level of eEF-2 was estimated after a 2 min incubation period in the presence of the indicated compounds by immunoblotting, using the antiphospho-eEF-2 antibody. Data are the means \pm SEM of results obtained by densitometric analysis of immunoreactive bands originating from at least three independent experiments, each performed on different sets of cultured neurons, and have been expressed in the percentage of the signal evoked by glutamate treatment. Cytosolic $\mathrm{Ca}^{2+}$ concentration $\left(\left[\mathrm{Ca}^{2+}\right]\right)$ was estimated in INDO-1-loaded cortical neurons 2 min after the onset of drug application, as indicated in Materials and Methods. Data represent the means \pm SEM of cytosolic $\mathrm{Ca}^{2+}$ concentration measured in 14 single neurons originating from two different cultures. The amount of phosphorylated eEF-2 and the cytosolic $\mathrm{Ca}^{2+}$ concentration were significantly correlated (Spearman rank correlation coefficient, $r_{\mathrm{s}}=1, p<0.02$ ).

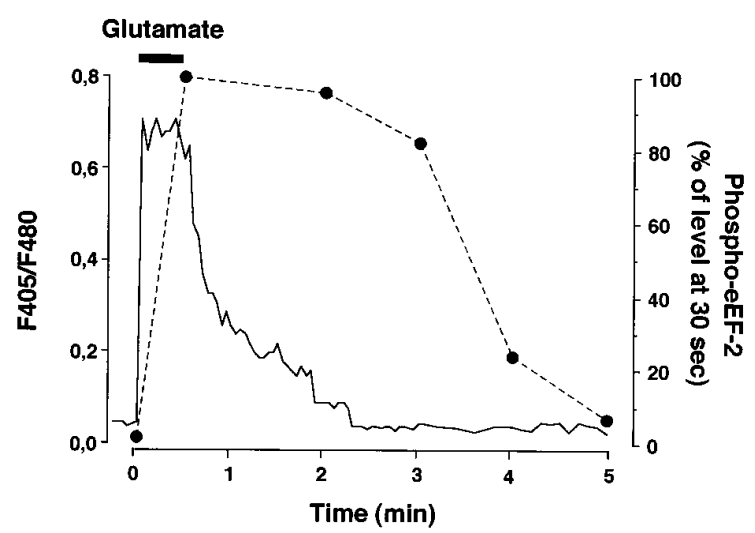

Figure 5. Reversibility of eEF-2 phosphorylation induced by glutamate. Cortical neurons, loaded with INDO-1, were exposed for $30 \mathrm{sec}$ to $100 \mu \mathrm{M}$ glutamate. Variations in cytosolic $\mathrm{Ca}^{2+}$ concentration (ratio between the fluorescence measured at 405 and $480 \mathrm{~nm}: F_{405} / F_{480}$ ) were measured for 5 min. A typical trace representative of those obtained in 28 neurons originating from two independent cultures is illustrated. The black horizontal bar indicates the period of exposure to glutamate. eEF-2 phosphorylation was measured at various times after glutamate application ( filled symbols). Quantified data were obtained from the densitometric analysis of a representative immunoblot by using the anti-phospho-eEF-2 antibody and were expressed in the percentage of the phosphorylation level, measured at $30 \mathrm{sec}$ of glutamate incubation time. Another experiment performed on a different set of cultured neurons yielded similar results.

$\left[{ }^{3} \mathrm{H}\right]$ leucine (data not shown). It should be noted that the uptake of either amino acid, as estimated by the radioactivity recovered in the TCA soluble fraction, was not affected significantly by gluta- 


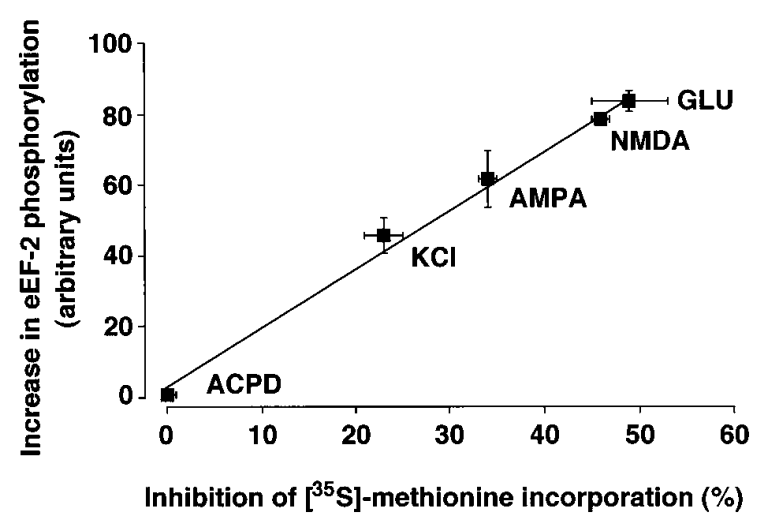

Figure 6. Correlation between the increase in eEF-2 phosphorylation and inhibition of $\left[{ }^{35} \mathrm{~S}\right] \mathrm{methionine}$ incorporation into proteins. The increase in eEF-2 phosphorylation induced by a 2 min application of $G L U(100 \mu \mathrm{M})$, $N M D A(200 \mu \mathrm{M}), A M P A(30 \mu \mathrm{M})$, trans-ACPD $(A C P D, 300 \mu \mathrm{M})$, and $K C l$ $(50 \mathrm{~mm})$, expressed in arbitrary units, was quantified by densitometric analysis of immunoreactive bands in immunoblotting experiments performed with the anti-phospho-eEF-2 antibody and plotted as a function of the inhibition of $\left[{ }^{35} \mathrm{~S}\right]$ methionine incorporation into proteins induced by the same treatments performed in Krebs' bicarbonate buffer $(r=0.996$, $p<0.001)$. $\left[{ }^{35} \mathrm{~S}\right]$ Methionine incorporation was calculated as the ratio of TCA-precipitable to TCA-soluble radioactivity and expressed as the percentage of inhibition of the basal incorporation measured during $5 \mathrm{~min}$ $(230,500 \pm 17,000 \mathrm{dpm} / \mathrm{mg}$ protein, $n=3)$. Values are mean \pm SEM of the data obtained in three experiments, each performed in triplicate on different cultures.

matergic agonists or cell depolarization (data not shown). A striking correlation was observed between the ability of the various treatments to increase eEF-2 phosphorylation and their efficacy to inhibit protein synthesis (Fig. 6). Moreover, as demonstrated above for eEF-2 phosphorylation, the inhibition of protein synthesis evoked by a 5 min exposure to glutamate involved both NMDA and AMPA receptors. The inhibitory effect of glutamate on protein synthesis was antagonized only by the combined application of MK-801 and CNQX, whereas either antagonist applied separately reversed only partially the response to glutamate (Table 2). As expected, trans-ACPD, which failed to increase cytosolic $\mathrm{Ca}^{2+}$ concentration and eEF-2 phosphorylation, did not inhibit $\left[{ }^{35} \mathrm{~S}\right]$ methionine incorporation into proteins in cortical neurons (Fig. 6). In agreement with the major role of $\mathrm{Ca}^{2+}$ in eEF-2 phosphorylation, the inhibition of protein synthesis induced by glutamate receptor agonists was suppressed when $\mathrm{Ca}^{2+}$ was removed and $1 \mathrm{~mm}$ EGTA was added to the incubation medium (data not shown). Interestingly, in this experimental condition the basal incorporation of $\left[{ }^{35} \mathrm{~S}\right] \mathrm{methionine} \mathrm{into} \mathrm{proteins}$ was inhibited by $21 \pm 2 \%$ (mean \pm SEM from three independent experiments). This might be explained by the concomitant increase in the level of eEF-2 phosphorylation after the removal of extracellular $\mathrm{Ca}^{2+}$ (Fig. 4).

\section{Effects of prolonged treatment with glutamate on eEF- 2 phosphorylation and protein synthesis}

A persistent and $\mathrm{Ca}^{2+}$-dependent inhibition of protein synthesis, together with a massive release of glutamate, has been described after cerebral ischemia (Benveniste et al., 1984; Raley-Susman and Lipton, 1990). To mimic the effects of the pathological release of glutamate, we exposed cortical neurons to glutamate $(100 \mu \mathrm{M})$ for prolonged periods of time (up to $60 \mathrm{~min}$ ). This treatment resulted in a sustained increase in cytosolic $\mathrm{Ca}^{2+}$ concentration (Fig. $7 a$ ). Neuronal viability was not altered immediately after the
Table 2. Contribution of AMPA and NMDA receptors to the glutamateinduced inhibition of protein synthesis

\begin{tabular}{lc} 
Treatment & $\begin{array}{l}{\left[{ }^{35} \text { S Methionine }\right.} \\
\text { incorporation } \\
(\% \text { of basal })\end{array}$ \\
\hline None & $100 \pm 7$ \\
MK-801 $(2 \mu \mathrm{M})$ & $112 \pm 8$ \\
CNQX $(100 \mu \mathrm{M})$ & $94 \pm 11$ \\
CNQX + MK-801 & $108 \pm 11$ \\
GLU $(100 \mu \mathrm{M})$ & $54 \pm 5^{a}$ \\
GLU + MK-801 & $71 \pm 9^{a}$ \\
GLU + CNQX & $59 \pm 5^{a}$ \\
GLU + MK-801 + CNQX & $91 \pm 5$
\end{tabular}

Neurons were exposed to antagonists for $1 \mathrm{~min}$ in Krebs' bicarbonate buffer before a $5 \mathrm{~min}$ incubation period in the presence of $\left[{ }^{35} \mathrm{~S}\right]$ methionine $(4 \mu \mathrm{Ci} / \mathrm{ml}) .\left[{ }^{35} \mathrm{~S}\right] \mathrm{Me}$ thionine incorporation, expressed in the percentage of the mean of basal $\left[{ }^{35} \mathrm{~S}\right] \mathrm{me}$ thionine incorporation measured in the absence of any treatment $(230,500 \pm 17,000$ $\mathrm{dpm} / \mathrm{mg}$ protein, $n=3$ ), was measured as indicated in the legend to Figure 6 . None of these treatments altered significantly the amount of TCA-soluble $\left[{ }^{35}\right.$ S $]$ methionine, indicating that they did not modify methionine uptake into neurons. All values are the means \pm SEM of data obtained in three experiments, each performed in triplicate on three different sets of cultured neurons.

${ }^{a}$ Significantly different $(p<0.01)$ from basal $\left[{ }^{35} \mathrm{~S}\right]$ methionine incorporation (ANOVA, followed by Dunnett's test).

60 min glutamate treatment because cellular respiration, assessed by the MTT staining method, was not decreased significantly (data not shown). This contrasted with the delayed neuronal death observed $24 \mathrm{hr}$ after this treatment $(26 \pm 5 \%$ of cell survival measured in three independent experiments).

The rate of protein synthesis was studied in the same experimental conditions by measuring amino acid incorporation during the last 5 min of glutamate treatment. To prevent any modification of endogenous amino acid concentration and, therefore, any change in the specific radioactivity of labeled amino acids, we added glutamate and radioactive amino acids directly to the culture medium without washing. With this procedure, a short (5 min) exposure to glutamate $(100 \mu \mathrm{M})$ decreased the incorporation of $\left[{ }^{35} \mathrm{~S}\right]$ methionine and $\left[{ }^{3} \mathrm{H}\right]$ leucine by $58 \pm 5$ and $69 \pm 2 \%(n=$ 3), respectively (Fig. 7b), similarly to what was measured in Krebs' bicarbonate buffer. The inhibition of $\left[{ }^{35} \mathrm{~S}\right]$ methionine and $\left[{ }^{3} \mathrm{H}\right]$ leucine incorporation remained sustained during prolonged glutamate application periods (up to $60 \mathrm{~min}$, Fig. $7 b$ ). In the same experimental conditions, the level of eEF-2 phosphorylation remained elevated as compared with the basal level, although a slow decrease was observed during prolonged treatment ( $\geq 30 \mathrm{~min}$ ) of cortical neurons with glutamate (Fig. 7c). This decrease in immunoreactivity measured with the anti-phospho-eEF-2 antibody was not attributable to proteolysis, because the total amount of eEF-2 remained unchanged (Fig. $7 c$ ).

The autophosphorylation of eEF-2 kinase has been reported to lead to a partial $\mathrm{Ca}^{2+}$-independent activity (Mitsui et al., 1993; Redpath and Proud, 1993). However, this process seems unlikely to contribute to the prolonged increase in eEF-2 phosphorylation, because eEF-2 kinase activities measured in cytosolic extracts from neurons exposed to glutamate $(100 \mu \mathrm{M})$ for 5 or $60 \mathrm{~min}$ remained strictly $\mathrm{Ca}^{2+}$-dependent (Fig. $7 d$ ). On the other hand, a prolonged exposure to glutamate $(60 \mathrm{~min})$ resulted in a partial decrease in $\mathrm{Ca}^{2+}$-dependent eEF-2 kinase activity (Fig. $7 d$ ). This decreased activity may account for the decrease in the amount of phosphorylated eEF-2 measured after prolonged glutamate treatments.

It has been reported that the multifunctional $\mathrm{Ca}^{2+} /$ calmodulin- 

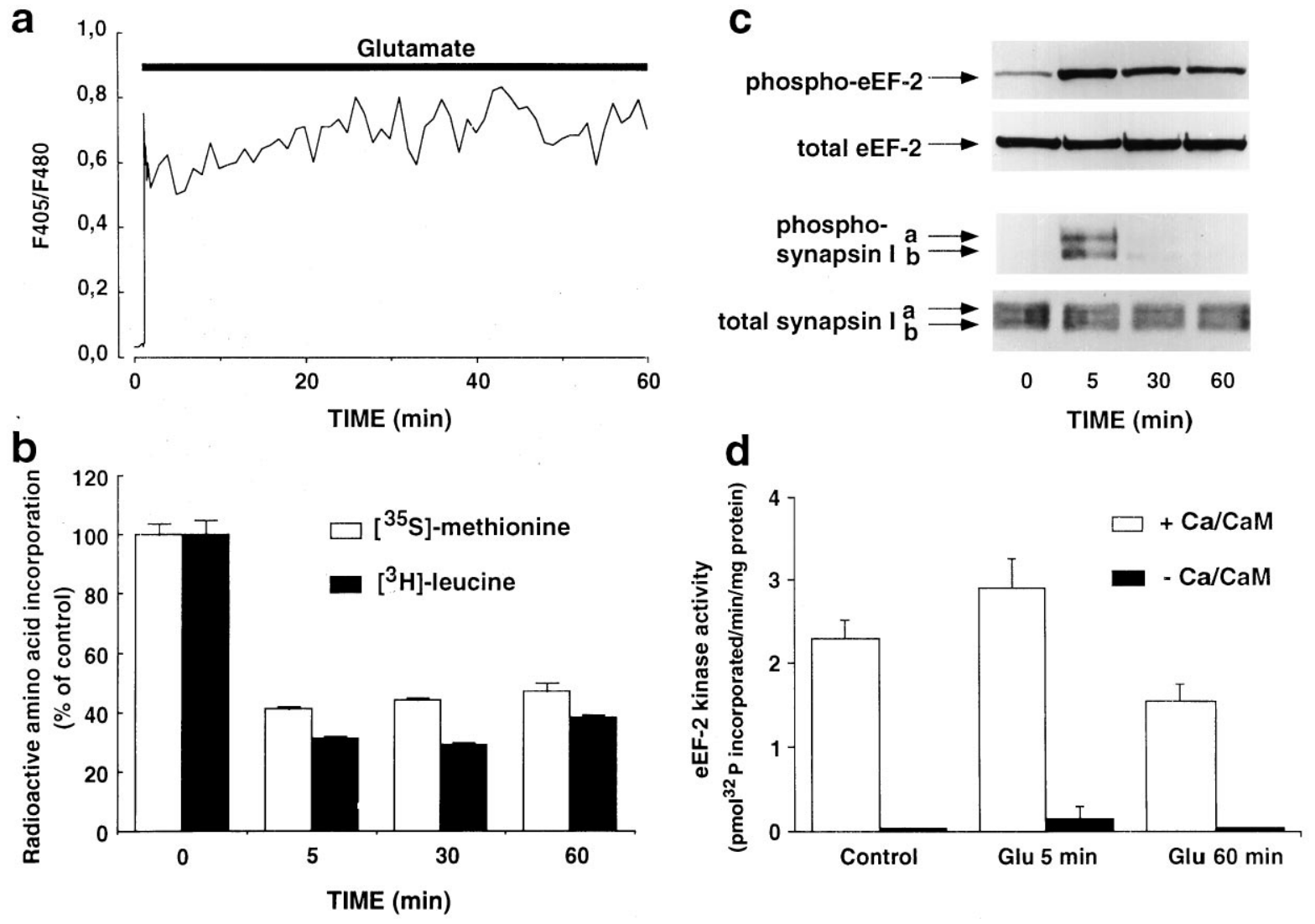

Figure 7. Effects of prolonged treatments with glutamate on cytosolic $\mathrm{Ca}^{2+}$, protein synthesis, eEF-2 and synapsin I phosphorylation, and $\mathrm{Ca}^{2+}$ dependency of eEF-2 kinase activity. $a$, Cytosolic $\mathrm{Ca}^{2+}$ concentration was measured for $60 \mathrm{~min}$ in INDO-1-loaded cortical neurons exposed to $100 \mu \mathrm{M}$ glutamate. A typical trace representative of those obtained in 28 different neurons originating from two independent cultures is illustrated. The horizontal black bar indicates the incubation period in the presence of glutamate. $b$, Cortical neurons were exposed to $100 \mu \mathrm{M}$ glutamate added directly to the culture medium for the indicated times. $\left[{ }^{35} \mathrm{~S}\right]$ Methionine $(1000 \mathrm{Ci} / \mathrm{mmol}, 4 \mu \mathrm{Ci} / \mathrm{ml})$ or $\left[{ }^{3} \mathrm{H}\right]$ leucine $(159 \mathrm{Ci} / \mathrm{mmol}, 4 \mu \mathrm{Ci} / \mathrm{ml})$ then was added to the culture medium for the last $5 \mathrm{~min}$ of the incubation period in the presence of glutamate. Results were calculated as indicated in the legend to Figure 6 and expressed in the percentage of basal $\left[{ }^{35}\right.$ S $]$ methionine $(99,500 \pm 1950 \mathrm{dpm} / \mathrm{mg}$ protein, $n=3)$ or $\left[{ }^{3} \mathrm{H}\right] \mathrm{leucine}(76,900 \pm 5900 \mathrm{dpm} / \mathrm{mg}$ protein, $n=3)$ incorporation into proteins. $c$, The phosphorylation state of eEF-2 was measured by immunoblotting, using the anti-phospho-eEF-2 antibody and the antibody recognizing total eEF-2 after various times of exposure to glutamate. The phosphorylation state of synapsin I on site 3 was estimated in the same experimental conditions by sequential immunoblotting with an anti-phospho-synapsin I antibody (1:1000 dilution) and an antibody that reacts with synapsin I independently of its state of phosphorylation (1:5000 dilution). $d$, eEF-2 kinase activity was determined in cytosolic extracts obtained from cortical neurons exposed for the indicated times to glutamate $(\mathrm{Glu})$ and containing $5 \mu \mathrm{g}$ of protein by measuring the incorporation of ${ }^{32} \mathrm{P}$ in $100 \mathrm{ng}$ of purified rabbit eEF-2 in the presence of either $1 \mathrm{~mm}$ EGTA, $1.5 \mathrm{~mm} \mathrm{Ca}{ }^{2+}$ and $20 \mu \mathrm{g} / \mathrm{ml}$ calmodulin $(+\mathrm{Ca} / \mathrm{CaM})$, or $1 \mathrm{mM}$ EGTA alone $(-\mathrm{Ca} / \mathrm{CaM})$. Incorporation of ${ }^{32} \mathrm{P}$ in eEF-2 was quantified by Cerenkov counting. Results are the means of three determinations, each performed on different sets of cultured neurons.

dependent protein kinase II (CaM kinase II) is strongly downregulated in neurons during prolonged exposure to glutamate (Churn et al., 1995; Morioka et al., 1995). We compared the phosphorylation of eEF-2 with that of synapsin I, a major neuronal substrate for CaM kinase II, using an antibody that reacts specifically with synapsin I phosphorylated on Ser 603 (site 3), a residue only phosphorylated by CaM kinase II (Czernik et al., 1995). During prolonged treatment with glutamate, the phosphorylation of synapsin I was transient (Fig. 7c), in contrast to the persistent phosphorylation of eEF-2.

\section{Role of eEF-2 phosphorylation in NMDA receptor-mediated neurotoxicity}

Further experiments were performed to determine the role of eEF-2 phosphorylation and the associated inhibition of protein translation in a classical paradigm of NMDA receptor-mediated neurotoxicity. When cortical neurons were exposed for $30 \mathrm{~min}$ to NMDA $(100 \mu \mathrm{M})$, a transient phosphorylation of eEF-2 preceded neuronal death by several hours (Fig. 8). The transitory phosphor- ylation of eEF-2 was followed by a decrease in the $\mathrm{Ca}^{2+}$. dependent eEF-2 kinase activity, which was observed after the removal of NMDA (Fig. 8c). This decrease in eEF-2 kinase activity may contribute to the transient nature of eEF-2 phosphorylation despite the persistent elevation of intracellular free $\mathrm{Ca}^{2+}$, which occurs after prolonged NMDA treatments (Schinder et al., 1996). The residual eEF-2 kinase activity measured in these experimental conditions also remained strictly $\mathrm{Ca}^{2+}$-dependent (data not shown).

To determine the possible role of protein synthesis inhibition in neuronal death, we have examined the effects of cycloheximide and diphtheria toxin, two drugs that block polypeptide chain elongation, as does eEF-2 phosphorylation. Neither cycloheximide $(1 \mu \mathrm{g} / \mathrm{ml}, 12 \mathrm{hr})$ nor diphtheria toxin $(10 \mathrm{nM}, 12 \mathrm{hr})$ treatments, both of which depressed strongly neuronal protein synthesis (by $89 \pm 4$ and $73 \pm 6 \%, n=3$, respectively), triggered neuronal death. On the contrary, both treatments protected neurons against the neurotoxic effect evoked by a low concentration 
a

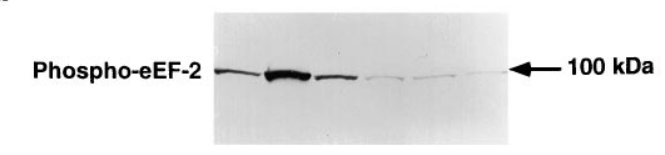

b
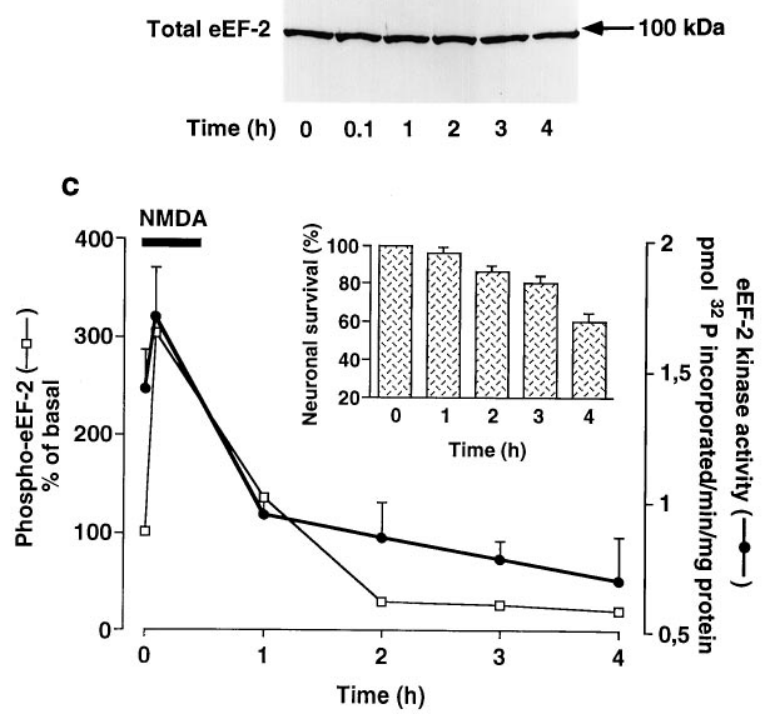

Figure 8. Comparison of the amount of phosphorylated eEF-2, eEF-2 kinase activity, and neuronal survival after NMDA treatment. Cortical neurons were exposed to $100 \mu \mathrm{M}$ NMDA for $30 \mathrm{~min}$. The phosphorylation state of eEF-2 was measured at various times after the onset of NMDA application by sequential immunoblotting, using the anti-phospho-eEF-2 antibody $(a)$ and the antibody recognizing total eEF-2 $(b)$. The data illustrated are representative of two experiments, each performed on different sets of cultured neurons. $c$, Phospho-eEF-2 immunoreactivity has been quantified by computer-assisted densitometric analysis. $\mathrm{Ca}^{2+} / \mathrm{CaM}-$ dependent eEF-2 kinase activity also was determined in the same experimental conditions. Neuronal survival (indicated in inset) was measured at the indicated times and is expressed as the percentage of cells surviving compared with that in the absence of any treatment. Results are the mean \pm SEM of values obtained in three independent experiments.

Table 3. Effects of protein translation inhibitors on NMDA receptormediated neurotoxicity

\begin{tabular}{lccc} 
& \multicolumn{3}{c}{ Neuronal survival $(\%)$} \\
\cline { 2 - 4 } Treatment & None & Cycloheximide & Diphtheria toxin \\
\hline None & 100 & $100 \pm 1$ & $99 \pm 2$ \\
NMDA $(10 \mu \mathrm{M})$ & $79 \pm 4$ & $96 \pm 4^{a}$ & $100 \pm 5^{a}$ \\
NMDA $(100 \mu \mathrm{M})$ & $47 \pm 2$ & $55 \pm 6$ & $42 \pm 1$ \\
\hline
\end{tabular}

Cortical neurons were exposed to the indicated concentrations of NMDA for $30 \mathrm{~min}$ Cycloheximide $(1 \mu \mathrm{g} / \mathrm{ml})$ was added to cells for $30 \mathrm{~min}$ before, during, and for $2 \mathrm{hr}$ after the NMDA incubation period. Diphtheria toxin (10 nM) was applied to cells 12 $\mathrm{hr}$ before the NMDA treatment. Neuronal survival was estimated $24 \mathrm{hr}$ after the onset of NMDA application by measuring the rate of MTT reduction. Results, expressed in the percentage of the neuronal survival estimated in the absence of any treatment, are the means \pm SEM of values obtained in three independent experiments, each performed in triplicate on different sets of cultured neurons.

${ }^{a}$ Significantly different $(p<0.01)$ from the neuronal survival estimated $24 \mathrm{hr}$ after a $10 \mu \mathrm{M}$ NMDA treatment (ANOVA, followed by Student-Newman-Keuls test).

of NMDA $(10 \mu \mathrm{M})$, but not that evoked by a higher concentration (100 $\mu \mathrm{M}$; Table 3$)$. Pretreatment of neurons with cycloheximide or diphtheria toxin had no effect on the increase in cytosolic $\mathrm{Ca}^{2+}$ induced by both 10 and $100 \mu \mathrm{M}$ NMDA (data not shown). These observations suggest that eEF-2 phosphorylation and the resulting inhibition of protein translation may constitute a protective mechanism against NMDA receptor-mediated neurotoxicity.

\section{DISCUSSION}

Inhibition of protein synthesis in brain slices by excitatory amino acids was reported almost 30 years ago (Orrego and Lipmann, 1967). Our results provide a possible mechanism that may contribute to this hitherto unexplained observation. Indeed, several lines of evidence suggest strongly that $\mathrm{Ca}^{2+}$-dependent phosphorylation of eEF-2 is involved in the inhibition of protein synthesis by glutamate. First, it has been clearly demonstrated in reconstituted systems in vitro that phosphorylation of eEF-2 by eEF-2 kinase, a $\mathrm{Ca}^{2+}$-dependent enzyme, inhibits protein translation (Nairn and Palfrey, 1987; Ryazanov et al., 1988). Second, treatment of cortical neurons with glutamate resulted concomitantly in the phosphorylation of eEF-2 to a stoichiometry of $\sim 0.5$ and in a $50 \%$ inhibition of protein synthesis. Moreover, immunofluorescence experiments using the anti-phospho-eEF-2 antibody indicated that only one-half of the neurons were strongly stained in response to glutamate. This suggests that the stoichiometry of eEF-2 phosphorylation is very high in a subset of glutamatetreated neurons. Third, a perfect correlation was observed among the increase in cytosolic $\mathrm{Ca}^{2+}$ concentration, the degree of eEF-2 phosphorylation, and the amplitude of protein synthesis inhibition in cortical neurons exposed to glutamatergic agonists or a depolarizing agent (glutamate $>$ NMDA $>$ AMPA $>\mathrm{KCl} \gg$ transACPD). Finally, the phosphorylation of eEF-2 and the inhibition of protein synthesis were both totally dependent on the presence of extracellular $\mathrm{Ca}^{2+}$.

The role of the phosphorylation of eEF-2 by eEF-2 kinase in the inhibition of protein synthesis has, to date, been investigated only in cell-free translation systems (Nairn and Palfrey, 1987; Ryazanov et al., 1988). Our study provides strong evidence that an increase in cytosolic $\mathrm{Ca}^{2+}$ and the resulting eEF-2 phosphorylation are also responsible for an inhibition of protein synthesis in living cells. Phosphorylation of eEF-2 may be of particular importance in neurons in which glutamate induces sustained and prolonged cytosolic $\mathrm{Ca}^{2+}$ elevations differing from the transient nature of $\mathrm{Ca}^{2+}$ increases induced by different effectors in most non-neuronal tissues (Palfrey and Nairn, 1995).

Besides the phosphorylation of eEF-2, the phosphorylation of the eukaryotic initiation factor eIF- $2 \alpha$ by double-stranded RNAregulated protein kinase (PKR) constitutes another potential $\mathrm{Ca}^{2+}$-dependent mechanism contributing to inhibition of protein synthesis (Prostko et al., 1995; Srivastava et al., 1995). The phosphorylation of eIF- $2 \alpha$ by PKR apparently is not related to an increase in cytosolic $\mathrm{Ca}^{2+}$ concentration but, rather, to a depletion of intracellular $\mathrm{Ca}^{2+}$ stores after long-term $\mathrm{Ca}^{2+}$ deprivation or treatment with $\mathrm{Ca}^{2+}$ mobilizing agents (Prostko et al., 1995; Srivastava et al., 1995). Because the inhibition of protein synthesis induced by glutamate was strictly dependent on the presence of extracellular $\mathrm{Ca}^{2+}$, a role of intracellular $\mathrm{Ca}^{2+}$ stores is unlikely. On the other hand, $\mathrm{Ca}^{2+}$ store depletion could be involved in the slight inhibition of protein synthesis observed when cortical neurons were incubated for $5 \mathrm{~min}$ in the absence of extracellular $\mathrm{Ca}^{2+}$ and in the presence of EGTA. However, this decrease in protein synthesis also could be related to the small increase in eEF-2 phosphorylation observed in this experimental condition.

Neuronal, but not glial, protein synthesis is believed to be persistently inhibited during the reperfusion phase of cerebral ischemia (Raley-Susman and Lipton, 1990). The massive release of glutamate that occurs in this pathological situation (Benveniste 
et al., 1984) may be responsible for the sustained inhibition of neuronal protein synthesis. During prolonged treatments of cortical neurons with glutamate, we observed a persistent phosphorylation of eEF-2, which was accompanied by a prolonged inhibition of protein synthesis. The prolonged phosphorylation of eEF-2 probably resulted from the persistent increase in cytosolic $\mathrm{Ca}^{2+}$. Indeed, eEF-2 kinase activity remained completely $\mathrm{Ca}^{2+}$. dependent, even after a prolonged exposure to glutamate, ruling out a role for the autophosphorylation of the kinase (Mitsui et al., 1993; Redpath and Proud, 1993). eEF-2 phosphorylation observed during a $60 \mathrm{~min}$ exposure to glutamate may be explained by the slight diminution of eEF-2 kinase activity, which occurs in the same experimental condition. In contrast to the sustained phosphorylation of eEF-2 observed during prolonged exposure to glutamate, the phosphorylation of synapsin I was only transient in cortical neurons. The rapid decrease in the phosphorylation of synapsin I may result from the rapid downregulation of $\mathrm{CaM}$ kinase II, already described in hippocampal neurons (Churn et al., 1995; Morioka et al., 1995). The contrast between the phosphorylation of eEF-2 and that of synapsin I during a prolonged treatment with glutamate emphasizes the diversity in the time course of various $\mathrm{Ca}^{2+}$-activated processes in response to persistent increases in cytosolic $\mathrm{Ca}^{2+}$.

It has been proposed recently that glutamate induces either apoptotic or necrotic neuronal cell damage, depending on the intensity and the duration of the stimulation of NMDA receptors (Bonfoco et al., 1995). Apoptosis is an active process requiring protein synthesis and thus is suppressed by protein synthesis inhibitors. Accordingly, cycloheximide, an elongation inhibitor, protected selectively cortical neurons against the neurotoxicity induced by a low concentration of NMDA, as it already has been described for retinal ganglion cells (Dreyer et al., 1995). Furthermore, diphtheria toxin treatment, which leads to ADPribosylation of eEF-2 and inhibition of its activity, also protected cortical neurons against cell damage evoked by a low concentration of NMDA. Therefore, inhibition of protein translation resulting from eEF-2 phosphorylation may represent a selfprotective mechanism against glutamate neurotoxicity.

In addition to its possible role in glutamate-induced neuronal death, eEF-2 phosphorylation and the associated inhibition of protein synthesis also may be involved in the modulation of normal physiological processes. It has been proposed that transient inhibition of protein synthesis by $\mathrm{Ca}^{2+}$-induced phosphorylation of eEF-2 may lead to an alteration in the pattern of protein expression (Ryazanov and Spirin, 1993; Palfrey and Nairn, 1995). Several mechanisms have been proposed to account for changes in protein expression after a transient inhibition of protein synthesis. First, it has been suggested that short-lived proteins are involved in the destabilization of specific mRNAs (for review, see Palfrey and Nairn, 1995). Transient inhibition of protein synthesis resulting from eEF-2 phosphorylation could lead to the rapid disappearance of these destabilizing proteins and, consequently, to a decrease in the degradation of normally unstable mRNAs. For instance, a striking effect of inhibitors of protein synthesis such as cycloheximide is the superinduction of the expression of immediate-early gene mRNAs, including $c$-fos, $c$-jun, and $c$-myc, that have very short half-lives (Greenberg et al., 1986; Cleveland and Yen, 1989). Inhibition of protein translation also can lead to the disappearance of proteins involved in the stabilization of some mRNAs. This may account for the destabilization of ligatin mRNA via a $\mathrm{Ca}^{2+}$-dependent mechanism observed in cultured hippocampal neurons treated with glutamate (Jakoi et al., 1995;
Panchision et al., 1995). Second, many transcription factors are themselves turned over rapidly, and it has been speculated that eEF-2 phosphorylation, by regulating the level of such factors, leads to a new pattern of gene expression (Ryazanov and Spirin, 1993; Palfrey and Nairn, 1995). Finally, elongation block, by stalling polypeptide extension, could force free ribosomal subunits to engage other mRNAs (Palfrey and Nairn, 1995). Thus, transient phosphorylation of eEF-2 could reset the protein translation machinery and participate in the transcriptional and translational regulations brought about by the various $\mathrm{Ca}^{2+}$-activated pathways.

Translational control involving eEF-2 phosphorylation potentially could contribute to the regulation of other glutamatedependent processes in neurons. The induction of long-term potentiation (LTP) in several brain regions, including the CA1 area and the dentate gyrus of the hippocampus, requires a rise in cytosolic $\mathrm{Ca}^{2+}$ concentration resulting from the activation of postsynaptic NMDA receptors (Bliss and Collingridge, 1993; Nicoll and Malenka, 1995). The application of protein synthesis inhibitors during the induction of LTP reduces its duration to 3-6 $\mathrm{hr}$, indicating that a critical level of protein synthesis is required for extension of LTP beyond several hours (for review, see Bliss and Collingridge, 1993). Transient phosphorylation of eEF-2 during the induction of LTP could interrupt ongoing protein synthesis, allowing the establishment of a new pattern of protein translation required for the maintenance of LTP. Interestingly, a selective enrichment in dendrites of specific mRNAs, including those encoding for MAP2 and the $\alpha$ subunit of CaM kinase II, has been reported (for review, see Steward, 1995). Despite the homogenous distribution of eEF-2 in cortical neurons, the location of its phosphorylated form appears to be restricted to cell bodies and proximal processes. This offers the potential for local regulation of the translation of specific proteins in the vicinity of postsynaptic sites in response to local increases in cytosolic $\mathrm{Ca}^{2+}$ concentration, which are required for the subsequent events leading to LTP. Therefore, the phosphorylation of eEF-2 and its consequences on translational control in neurons open up new perspectives for understanding acute as well as long-term effects of glutamate.

\section{REFERENCES}

Benveniste H, Drejer J, Schousboe A, Diemer NH (1984) Elevation of the extracellular concentrations of glutamate and aspartate in rat hippocampus during transient cerebral ischemia by intracerebral microdialysis. J Neurochem 43:1369-1374.

Bliss TVP, Collingridge GL (1993) A synaptic model of memory: longterm potentiation in the hippocampus. Nature 361:31-39.

Bonfoco E, Krainc D, Ankarcrona M, Nicotera P, Lipton SA (1995) Apoptosis and necrosis: two distinct events induced, respectively, by mild and intense insults with $N$-methyl-D-aspartate or nitric oxide/ superoxide in cortical cell cultures. Proc Natl Acad Sci USA 92:7162-7166.

Chamak B, Fellous J, Glowinski J, Prochiantz A (1987) MAP2 expression and neuritic outgrowth and branching are coregulated through region-specific neuro-astroglial interactions. J Neurosci 7:3163-3170.

Choi DW (1992) Excitotoxic cell death. J Neurobiol 23:1261-1276.

Churn SB, Limbrick D, Sombatti S, DeLorenzo RJ (1995) Excitotoxic activation of the NMDA receptor results in inhibition of calcium/ calmodulin kinase II activity in cultured hippocampal neurons. J Neurosci 15:3200-3214.

Cleveland DW, Yen TJ (1989) Multiple determinants of eukaryotic mRNA stability. New Biol 1:121-126.

Coyle JT, Puttfarcken P (1993) Oxidative stress, glutamate, and neurodegenerative disorders. Science 262:689-695.

Czernik AJ, Mathers J, Tsou K, Greengard P, Mische SM (1995) Phosphorylation state-specific antibodies: preparation and applications. Neuroprotocols 6:56-61. 
Dessi F, Ben-Ari Y, Charriaut-Marlangue C (1994) Increased synthesis of specific proteins during glutamate-induced neuronal death in cerebellar culture. Brain Res 654:27-33.

Dreyer EB, Zang D, Lipton SA (1995) Transcriptional and translational inhibition blocks low dose NMDA-mediated cell death. NeuroReport 6:942-944.

Greenberg ME, Hermanowski AL, Ziff EA (1986) Effects of protein synthesis inhibitors on growth factor activation of c-fos, c-myc, and actin gene transcription. Mol Cell Biol 6:1050-1057.

Grynkiewicz ZG, Poenie M, Tsien R (1985) A new generation of $\mathrm{Ca}^{2+}$ indicators with greatly improved fluorescence properties. J Biol Chem 260:3440-3450.

Hincke MT, Nairn AC (1992) Phosphorylation of elongation factor-2 during $\mathrm{Ca}^{2+}$-mediated secretion from rat parotid acini. Biochem $\mathrm{J}$ 282:877-882.

Jakoi ER, Panchision DM, Gerwin CM, DeLorenzo RJ (1995) Posttranscriptional regulation of gene expression in hippocampal neurons by glutamate receptor activation. Brain Res 693:124-132.

Mackie KP, Nairn AC, Hampel G, Lam G, Jaffe EA (1989) Thrombin and histamine stimulate the phosphorylation of elongation factor-2 in endothelial cells. J Biol Chem 264:1748-1753.

Mitsui K, Brady M, Palfrey HC, Nairn AC (1993) Purification and characterization of calmodulin-dependent protein kinase III from rabbit reticulocytes and rat pancreas. J Biol Chem 268:13422-13433.

Moldave K (1985) Eukaryotic protein synthesis. Annu Rev Biochem 54:1109-1149.

Morioka M, Fukunaga S, Kurino M, Ushio Y, Miyamoto E (1995) Glutamate-induced loss of $\mathrm{Ca}^{2+} /$ calmodulin-dependent protein kinase II in cultured rat hippocampal neurons. J Neurochem 64:2132-2139.

Murphy NP, Cordier J, Glowinski J, Prémont J (1994) Is protein kinase $\mathrm{C}$ activity required for the $N$-methyl-D-aspartate-evoked rise in cytosolic $\mathrm{Ca}^{2+}$ in mouse striatal neurons? Eur J Neurosci 6:854-860.

Nairn AC, Palfrey HC (1987) Identification of the major $M_{\mathrm{r}} 100,000$ substrate for calmodulin-dependent protein kinase III in mammalian cells as elongation factor-2. J Biol Chem 262:17299-17303.

Nicoll RA, Malenka RC (1995) Contrasting properties of two forms of long-term potentiation in the hippocampus. Nature 377:115-118.

Nowak L, Bregestovski P, Ascher P, Herbet A, Prochiantz A (1984) Magnesium gates glutamate-activated channels in mouse central neurons. Nature 307:462-465.

Orrego F, Lipmann F (1967) Protein synthesis in brain slices. J Biol Chem 242:665-671.

Ovchinnikov LP, Motuz LP, Natapov PG, Averbuch LJ, Wettenhall REH, Szyszka R, Kramer G, Hardesty B (1990) Three phosphorylation sites in elongation factor-2. FEBS Lett 275:209-212.

Palfrey HC, Nairn AC (1995) Calcium-dependent regulation of protein synthesis. Adv Second Messenger Phosphoprotein Res 30:191-223.

Palfrey HC, Nairn AC, Muldoon NN, Villereal ML (1987) Rapid activation of calmodulin-dependent protein kinase III in mitogen-stimulated fibroblasts: correlation with intracellular $\mathrm{Ca}^{2+}$ transients. J Biol Chem 262:9785-9792.

Panchision DM, Gerwin CM, DeLorenzo RJ, Jakoi ER (1995) Glutamate receptor activation regulates mRNA at both transcriptional and posttranscriptional levels. J Neurochem 65:969-977.

Price NT, Redpath NT, Severinov KV, Campbell DG, Russel JM, Proud CG (1991) Identification of the phosphorylation sites in elongation factor-2 from rabbit reticulocytes. FEBS Lett 282:253-258.
Prostko CR, Dholakia JN, Brostrom MA, Brostrom CO (1995) Activation of the double-stranded RNA-regulated protein kinase by depletion of endoplasmic reticular calcium stores. J Biol Chem 270:6211-6215.

Raley-Susman KM, Lipton P (1990) In vitro ischemia and protein synthesis in the rat hippocampal slices: the role of calcium and NMDA receptor activation. Brain Res 515:27-38.

Redpath NT, Proud CG (1990) Activity of protein phosphatases against initiation factor-2 and elongation factor-2. Biochem J 272:175-180.

Redpath NT, Proud CG (1993) Purification and phosphorylation of elongation factor-2 kinase from rabbit reticulocytes. Eur $\mathrm{J}$ Biochem 212:511-520.

Redpath NT, Price NT, Severinov KV, Proud CG (1993) Regulation of elongation factor-2 by multisite phosphorylation. Eur $\mathbf{J}$ Biochem 213:689-699.

Ryazanov AG (1987) $\mathrm{Ca}^{2+} /$ calmodulin-dependent phosphorylation of elongation factor-2. FEBS Lett 214:331-334.

Ryazanov AG, Spirin AS (1993) Phosphorylation of EF2: a mechanism to shut off protein synthesis for reprogramming gene expression. In: Translational regulation of gene expression 2 (Ilan J, ed), pp 433-455. New York: Plenum.

Ryazanov AG, Shestakova EA, Natapov PG (1988) Phosphorylation of elongation factor-2 by EF-2 kinase affects rate of translation. Nature 334:170-173.

Schinder AJ, Olson EC, Spitzer NC, Montal M (1996) Mitochondrial dysfunction is a primary event in glutamate neurotoxicity. J Neurosci 16:6125-6133.

Smith PK, Krohn RI, Hermanson GT, Mallia AK, Gartner FH, Provenzano MD, Fujimoto EK, Goeke NM, Olson BJ, Klenk DC (1985) Measurement of protein using bicinchoninic acid. Anal Biochem 150:76-85.

Snyder GL, Girault JA, Chen JYC, Czernik AJ, Kebabian JW, Nathanson JA, Greengard P (1992) Phosphorylation of DARPP-32 and protein phosphatase inhibitor-1 in rat choroid plexus: regulation by factors other than dopamine. J Neurosci 12:3071-3083.

Srivastava SP, Davies MV, Kaufman RJ (1995) Calcium depletion from the endoplasmic reticulum activates the double-stranded RNAdependent protein kinase (PKR) to inhibit protein synthesis. J Biol Chem 270:16619-16624.

Steward O (1995) Targeting of mRNA to subsynaptic microdomains in dendrites. Curr Opin Neurobiol 5:55-61.

Thilmann R, Xie Y, Kleihues P, Kiessling M (1986) Persistent inhibition of protein synthesis precedes delayed neuronal death in postischemic gerbil hippocampus. Acta Neuropathol (Berl) 71:88-93.

Trovéro F, Marin P, Tassin JP, Prémont J, Glowinski J (1994) Accelerated resensitization of the D1 dopamine receptor-mediated response in cultured cortical and striatal neurons from the rat: respective role of $\alpha 1$-adrenergic and $N$-methyl-D-aspartate receptors. J Neurosci 14:6280-6288.

Vornov JJ, Coyle JT (1991) Glutamate neurotoxicity and the inhibition of protein synthesis in the hippocampal slice. $\mathrm{J}$ Neurochem 56:996-1006.

Weiss S, Pin JP, Sebben M, Kemp DE, Sladeczek F, Gabrion J, Bockaert J (1986) Synaptogenesis of cultured striatal neurons in serum-free medium: a morphological and biochemical study. Proc Natl Acad Sci USA 83:2238-2242. 